\title{
SITEM PERSIAPAN LAHAN DAN PEMBERIAN BAHAN ORGANIK PADA BUDIDAYA JAGUNG DI LAHAN KERING
}

\author{
Ridwan dan Yulinar Zubaidah \\ Balai Pengkajian Teknologi Pertanian Sumatera Barat
}

\begin{abstract}
Land preparation and organic matter application was chosen as an alternative to improve soil physical, chemical, and biological properties in increasing yield of maize. The field experiment was conducted in Koto Baru Simalanggang, Lima Puluh Kota Regency, West Sumatra, in the dry season 2007. The treatments consist of three types of land preparation ( no tillage, direct composting in the area, and strip tillage) and two levels of organic matter application ( 0 and 2 $\mathrm{t} / \mathrm{ha}$ ). Objectives of the experiment were to observe the effect of land preparation methods and organic matter application on growth and yield of maize in the upland area. Results of the experiment showed that, land preparation types did not give significant effect on all parameter observed. Application of organic matter $2 \mathrm{t} / \mathrm{ha}$ had increased cob length, number of seed per row, and yield of maize. Maize yield was about $6.07 \mathrm{t} / \mathrm{ha}$ without and $6.85 \mathrm{t} / \mathrm{ha}$ with organic matter application.
\end{abstract}

Key Words : Land preparation System, Organic Matter Application, Maize, U pland Area.

\section{PENDAHULUAN}

Pada lahan yang selalu ditanami jagung sepanjang musim, untuk pertanman selajutnya tidak perlu dilakukan pengolahan tanah yang lebih intensif, karena struktur tanahnya sudah gembur karena selalu diolah pada setiap musim tanam, dan pengolahan tanah hanya ditujukan untuk pengendalian gulma.

Pengolahan tanah yang intensif dilakukan pada setiap musim tanam bertujuan untuk merobah struktur tanah jagi gembur, aerasi dan kapsitas infiltrasi meningkat, pertumbuhan gulma menurun, ketersediaan hara meningkat sehingga dapat meningkatkan produksi tanaman (Foth, 1988). Namun hal ini hanya bersifat sementara hal tersebut hanya bersifat sementara, terutama sekali di daerah tropic seperti Indonesia yang suhu dan curah hujannya tinggi di sepanjang musim akan menyebabkan tingkat dekomposisi dan mineralisasi akan dipercepat. Apabila dilakukan pengolahan tanah yang intensif setiap musim tanam akan memacu terjadinya erosi dan akan berakibat merosotnya kesuburan tanah karena terjadinya pencucian sejumlah unsure hara di samping meningkatnya polusi air sungai (Utomo, 2000).
Dari hasil penelitian terlihat bahwa, pada lahan yang selalu ditanami dengan jagung secara berurutan di sepanjang musim berbagai sistem pengolahan tanah untuk pertanaman janung selanjutnya tidak berpengaruh terhadap pertumbuhan dan hasil. Hal ini disebabkan struktur tanahnya sudah gembur karena selalu diolah setiap penanaman.

Untuk lahan yang struktur tanahnya sudah gembur dan ringan sistem pengolahan tanah yang tepat adalah dengan sistem TOT (tanpa olah tanah), olah tanah minimum seperti olah tanah dalam barisan ataupun dengan sistem KLD (kompos langsung di lahan), karena sistem ini lebih hemat tenaga kerja, biaya dan waktu.

Sistem pengolahan tanah pada lahan yang selalu ditanami jagung sepanjang musim sering dihubungkan dengan dengan penggunaan bahan bahan organik, karena tanaman jagung dapat menghasilkan limbah yang banyak yaitu sekitar 5-6 ton jerami kering disetiap panen (Soepardi et al, 1985) belum lagi termasuk limbah lainnya seperti kelobot dan tongkol serta gulma iisitu.. Limbah tersebut dapat dimanfaatkan sebagai sumber bahan organik insitu pada sistem TOT ataupun pada sistem KLD

Pemberian baha organik dalam bentuk kompos ataupun pupuk kandang merupakan salah satu komponen teknologi pada 
budidaya jagung. Dalam komponen teknologi yang diterapkan pada PTT jagung bahan organik dalam bentuk pupuk kandang diberikan dengan takaran 1,5 -2,0 t/ha dan cara pemberiannya ditempatkan pada lobang tanam sebagai penutup benih (Badan Litbang, 2008).

Bahan organik selain berfungsi sebagai pembenah tanah juga dapat meningkatkan kesuburan tanah karena dapat menyumbangkan sejumlah unsur hara makro dan mikro yang sangat dibutuhkan oleh tanaman. Pemberian bahan organik dengan takaran yang tinggi dapat mngurangi penggunaan pupuk kimia. Lahan pertanian yang diusahakan secara intensif sepanjang tahun sudah mengalami degradasi yang ditandai dengan rendahnya kandungan corganik tanah yaitu $<2 \%$ kedaan ini akan lebih parah apabila setiap musim panen limbah tanaman diangkut keluar lapangan (Abdurachman et al, 2008).

Dari hasil penelitian yang dilaksanakan pada lahan sawah tadah hujan di Surantih kabupaten Pesisir Seltan terlihat bahwa pemberian bahan organik dalam bentuk pupuk kandang dan kompos merupakan salah satu faktor penentu terhadap peningkatkan hasil jagung. Pemberian pupuk dengan takaran Urea $250 \mathrm{~kg} / \mathrm{ha}+$ SP36 100 $\mathrm{kg} / \mathrm{ha}+\mathrm{KCl} 100 \mathrm{~kg} / \mathrm{ha}$ pada jagung varietas Bisma dan hibrida $\mathrm{C} 7$ masing-masing dapat memberikan hasil sebesar 6,81 dan 7,09 t/ha, dan bila dilengkapi dengan pemberian pupuk 2 t/ha hasil dari masing-masing varietas meningkat jadi 7,98 dan 8,41 t/ha (BPTP Sumbar, 2002). Untuk melihat pengaruh sistem pengolahan tanah dan pemberian bahan organik (pupuk kandang) pada tanaman jagung yang ditanam pada lahan yang ditanami jagung sepanjang musim perlu dilakukn penelitian.

Penelitian bertujuan untuk melihat pengaruh sistem persiapan lahan atau pengolahan tanah dan pemberian bahan organik terhadap tanaman jagung dan untuk mendapatkan sistem persiapan lahan yang terbaik dan menguntungkan serta menetapkan perlu atau tidaknya pemberian bahan organik pada tanaman jagung.

\section{BAHAN DAN METODE}

Kegiatan penelitian dilaksanakan pada lhn yang selalu ditanami dengan jagung sepnjng msim di kenagarian Koto Baru Simalanggang Kabupaten 50 Kota Provinsi Sumatera Barat pada MK. 2007. Perlakuan terdiri dari 3 sistem persiapan lahan (TOT, KLD dan ODB) dan 2 tingkat pemberian pupuk kandang (tanpa dan 2,0 t/ha). Pada sistem TOT (tanpa olah tanah) 10 hari sebelum tanam lahan disemprot dengan herbisida Round Up (4 1/ha), batang jagung yang bersal tanamandari tanaman sebelumnya dipotong dan disusun sejajar dengan barisan tanaman dan penanaman dengan sistem membuat lobang di samping bumbun tanamn sebelumnya. Sistem KLD (kompos langsung dilahan), batang jagung dari tanaman sebelumnya dipotong dan disusun sejajar dengan barisan tanaman atau bumbun tanaman sebelumnya kemudian ditimbun dengan cara membelah kiri dan kanan bumbun tanaman jagung sebelumnya, sehingga lahan terlihat bersih dari sisa tanaman dan gulma. Sistem ODB (olah tanah dalam barisan), lahan hanya diolah pada barisan yang akan ditanami yaitu dengan cara membelah bumbun tanaman sebelumnya, pada sistem ini sisa tanaman tidak dibenam tetapi dibiarkan dipermukn tanah sampai wktu pembumbunan, saat pembumbunan sisa -sisa tanaman dan gulma ikut ditimbun pada barisan tanaman.

Jagung yang ditanam adalah hibrida Pionir-12 dengan jarak tanam sistem baris ganda (double row, $100 \times(40 \times 40 \mathrm{~cm}), 2$ benih/lobang. Pupuk diberikan dengan takaran Urea $250 \mathrm{~kg} / \mathrm{ha}+\mathrm{SP} 36100 \mathrm{~kg} / \mathrm{ha}$ +KCl $100 \mathrm{~kg} / \mathrm{ha}+$ pupuk kandang 2,0 t/ha. Seluruh takaran pupuk kandang, pupuk SP36 dan 1/3 takaran Urea dan $\mathrm{KCl}$ diberikan waktu tanam dan sisanya diberikan 35 HST bersamaan dengan pembumbunan. Cara pemberian pupuk kandang ditempatkan pada lobang tanam untuk menutup lobang benih yang baru ditanam. Penyiangan dilakukan bersamaan dengan pembumbunan, dimana sisa-sisa tanaman dan gulma yang terdapat di antara baris tanaman ditarik kebarisan tanaman dan ditimbun dengan cara menarik tanah diantara barisan ke dalam barisan sehingga akan membentuk guludan. 
Pengendalian hama dan penyakit dilakukan pada saat tanam, untuk pengendalian hama waktu tanam diberi Kurater -3G (17 kg/ha) yang ditempatkan pada lobang tanam, pengendalian penyakit dengan perlakuan benih (seed treatment) sebelum tanam benih dibasahi dengan air kemudian ditaburi bubuk Saromil (3,5 g/kg benih jagung), sebelum tanam benih dikering anginkan pada tempat yang teduh.

Parameter yang diamati terdiri dari analisa tanah awal, tinggi tanaman, panjang tongkol, lingkaran tongkol, jumah baris biji/tongkol. Jumlah biji/baris, berat 100 biji dan hasil biji kering (t/ha) serta data iklim (curh hujan).

\section{HASIL DAN PEMBAHASAN}

Analisa Tanah Awal

Hasil analisa tanah awal menunjukan tanah bereaksi masam, C-organik tinggi, $\mathrm{N}$ total dan $\mathrm{C} / \mathrm{N}$ ratio sedang. Nilai tukar kation, Ca-dd, Mg-dd, dan Na-dd tergolong rendah, K-dd dan KTK tergolong sedang (Tabel 1). Kondisi ini masih cocok untuk tanaman jagung, namun untuk berproduksi secara optimal sepanjang musim tanam perlu pengelolaan yang lebih intensif, guna mempertahankan kelestarian lahan. Meskipun kadar bahan organik tanah tergolong tinggi dan P2O5 sangat tinggi, untuk mempertahankan kesuburan tanah perlu pengelolaan, yang tepat. Pengelolaan kesuburan tanah tidak hanya dengan pemberian pupuk saja tetapi juga dengan perbaikan sifat fisis tanah, sehingga tersedia lingkungan yang baik pertumbuhan tanaman, kehidupan mikroba tanah untuk prosese penting dalam tanah (Soepardi, 2001 dalam Abduracman et al, 2008). Hal ini dapat dicapai melalui pemupukan berimbang,dan pemberian bahan organik dalam bentuk kandang dan kompos (kompos insitu) pada setiap usim tanam serta dengan perbaikan sistem persiapan lahan atau pengolahan tanah.

Tabel 1.Sifat kimia tanah di lahan peneli tian, Koto Baru Simlnggang Kabupaten 50 Kota pada MK. 2007.

\begin{tabular}{|c|c|l|}
\hline Parameter & Nilai & \multicolumn{1}{|c|}{ Kriteria *) } \\
\hline $\mathrm{pH} \mathrm{H} 2 \mathrm{O}$ & 5,40 & Masam \\
$\mathrm{KCl}$ & 5,35 & Masam \\
C-Organik (\%) & 3,80 & Tinggi \\
N-Total (\%) & 0,22 & Sedang \\
C/N ratio (\%) & 12,72 & Sedang \\
P2O5 Bray II (ppm) & 120,00 & Sangat tinggi \\
Ca-dd (me/100g) & 4,82 & Rendah \\
Mg-dd (me/100g) & 0,50 & Rendah \\
Na-dd (me/11g) & 0.38 & Rendah \\
K-dd (me/100g) & 0,59 & Sedang \\
KTK (me/100g) & 0,36 & Sedang \\
\hline
\end{tabular}

*) Hardjowigeno (1987) 
Tinggi Tanaman

Tabel 2. Pengaruh sistem persiapan lahan dan pemberian bahan organik terhadap tinggi tanaman Jagung, (m), Koto Baru Simalanggang Kabupaten 50 Kota, Mk. 2007

\begin{tabular}{|c|c|c|l|l|}
\hline $\begin{array}{c}\text { Takaran B.Organik } \\
(\mathrm{t} / \mathrm{h})\end{array}$ & TOT & KLD & ODB & Rata-rata \\
\hline 0 & 1,75 & 1,87 & 1,80 & $1,81 \mathrm{a}$ \\
2 & 1,88 & 1,87 & 1,90 & $1,88 \mathrm{a}$ \\
\hline Rata-rata & $1,82 \mathrm{~A}$ & $1,87 \mathrm{~A}$ & $1,85 \mathrm{~A}$ & \\
\hline
\end{tabular}

Angka-angka selajur dan kolom yang diikuti oleh huruf sama tidak berbeda nyata pada UBD $(\mathrm{p}=0,05)$.

Perbedaan sistem persiapan lahan dan pemberian bahan organik (pupuk kandang) tidak berpengaruh secara nyata terhadap pertumbuhan tinggi tanaman (Tabel 2). Tiga sistem persiapan lahan (TOT, KLD dan ODB) yang diuji tidak banyak pengaruhnya terhadap tinggi tanaman. Hal ini disebabkan lahan yang selalu diusahakan secara intensif sepanjang musim tanam struktur tanahnya sudah gembur sehingga tindakan pengolahan tanah tidak berpengaruh terhadap pertumbuhan dan hasil tanaman selanjutnya, ada kalanya pengolahan tanah dapat berdampak negatif terhadap tanaman terutama pada musim, dimana pengolahan tanah yang intensif pada musim kering akan mempercepat kehilangan air tanah melalui evaporasi (Parker, 1983). Sistem persiapan lahan yang terbaik untuk tanaman jagung pada lahan yang selalu ditanami sepanjang musim adalah dengan sistem olah tanah konservasi termasuk di antaranya dengan sistem TOT (tanpa olah tanah) ataupun dengan sistem olah tanah minimum, karena sistem ini lebih hemat tenaga, biaya dan waktu. Hal yang sama juga terlihat pada pemberian bahan organik (pupuk kandang), dimana pemberian bahan organik sebanyak 2,0 t/ha tidak banyak pengaruhnya terhadap pertumbuhan tanaman. Karena lahan yang selalu ditanami dengan jagung sepanjang musim kondisinya tanahnya sudah baik akibat selalu diberi pupuk dan bahan organik (pupuk kandang),sehingga pemberian bahan organik pada pertanaman selanjutnya tidak menunjukan pengaruh yang nyata terhadap pertumbuhan tanaman, hal ini terlihat pada tinggi tanaman.. Meskipun pemberian bahan organik ini tidak banyak pengaruhnya terhadap pertumbuhan tanaman, tetapi masih tetap dianjurkan untuk pertanaman selanjutnya guna memperahankan kesuburan tanah dan perbaikan sifat-sifat fisis tanah, karena penanaman jagung tetap dilakukan sepanjang musim tanam.

Panjang Tongkol, Lingkaran Tongkol , Jumlah Baris Biji/Tongkol dan Jumlah Biji/Baris

Perbedaan sistem persiapan lahan tidak berpengaruh nyata terhadap pnjang tongkol, lingkaran tongkol, jumlah baris biji/tongkol dan jumlah biji/baris. Sedangkan pemberian bahan organik pengaruhnya nyata terhadap panjang tongkol, dan jumlah biji/baris. Lingkaran tongkol dan jumlah baris biji/tongkol tidak dipengaruhi oleh pemberian organik (Tabel 3).Persiapan lahan dengan sistem TOT, KLD dan ODB masing-masing tidak menunjukan pengaruh yang nyata terhadap ukuran tongkol, jumlah baris biji/tongkol dan jumlah biji/baris. Hal ini disebabkan lahan yang selalu ditanami jagung sepanjang musim struktur tanahnya sudah gembur, karena setiap musim tanam lahan selalu diolah baik sebelum tanam maupun saat pembumbunan. , sehingga tindakan pengolahan tanah lebih banyak diarahkan pada pengendalian gulma.

Pemberian bahan organik (pupuk kandang) masih diperlukan untuk tanaman disetiap musim tanam, karena dengan pemberian bahan organik sebanyak 2 t/ha dapat meningkatkan ukuran panjang tongkol dan jumlah biji/baris pada tongkol Tanpa pemberian bahan organik 
Tabel 3. Pengaruh sistem persiapan lahan dan pemberian bahan organik terhadap panjang tongkol, lingkaran tongkol, jumlah baris biji/tongkoldan jumlah biji/baris, Koto Baru Simalanggang Kabupaten 50 Kota, MK.2007.

\begin{tabular}{|c|c|c|c|c|}
\hline Perlakuan & $\begin{array}{l}\text { Pjg. Tongkol } \\
(\mathrm{cm})\end{array}$ & $\begin{array}{l}\text { Lkr. Tongkol } \\
(\mathrm{cm})\end{array}$ & $\begin{array}{l}\text { Jlh. Baris } \\
\text { biji/ } \\
\text { tongkol }\end{array}$ & $\begin{array}{l}\text { Jlh. Biji/ } \\
\text { baris }\end{array}$ \\
\hline $\begin{array}{l}\text { Sistem Persiapan Lahan } \\
\text { TOT } \\
\text { KLD } \\
\text { ODB }\end{array}$ & $\begin{array}{l}17,7 \mathrm{~A} \\
18,2 \mathrm{~A} \\
17,5 \mathrm{~A}\end{array}$ & $\begin{array}{ll}16,1 & \mathrm{~A} \\
16,4 & \mathrm{~A} \\
16,5 \mathrm{~A}\end{array}$ & $\begin{array}{ll}14,0 & \mathrm{~A} \\
14,1 & \mathrm{~A} \\
13,8 & \mathrm{~A}\end{array}$ & $\begin{array}{l}39,5 \mathrm{~A} \\
41,2 \mathrm{~A} \\
41,5 \mathrm{~A}\end{array}$ \\
\hline $\begin{array}{c}\text { Takaran B. Oranik (t/ha) } \\
0 \\
2\end{array}$ & $\begin{array}{l}17,1 \mathrm{~b} \\
18,4 \mathrm{a}\end{array}$ & $\begin{array}{l}15,9 \text { a } \\
16,6 \text { a, }\end{array}$ & $\begin{array}{l}13,9 \mathrm{a} \\
14,0 \mathrm{a}\end{array}$ & $\begin{array}{l}39,0 \mathrm{~b} \\
42,2 \mathrm{a}\end{array}$ \\
\hline
\end{tabular}

Angka-angka selajur yang diikuti oleh huruf sama tidak berbeda nyata pada UBD $(p=0,05)$

panjang tongkol hanya $17,1 \mathrm{~cm}$, dengan pemberian bahan organik meningkat jadi $18,4 \mathrm{~cm}$, hal yang sama juga terlihat pada pertambahan jumlah biji /baris pada tongkol, tanpa pemberian bahan organik jumlah biji 390,0/baris dengan pemberian bahan sebanyak 2 t/ha meningkat jadi 42,2/baris Berarti dengan pemberian bahan organik 2 t/ha dapat mengakibatkan ukuran tongkol yang terbentuk lebih panjang dan dapat menghasikan biji dengan jumlah yang lebih banyak.

Pemberian bahan organik dalam bentuk pupuk kandang ataupun kompos, dapat dimanfaatkan sebagai sumber hara. bagi tanaman di samping dapat memperbaiki sifat-sifat fisis , kimia dan biologi tanah, sehingga pemberian bahan organik perlu dilakukan pada setiap musim tanam. Guna mempertahankan kesuburan tanah.

\section{Berat 100 biji}

Sistem persiapan lahan terhadap berat 100 biji dan hasil pengaruhnya tidak nyata .Sedangkan pemberian bahan organik berpengaruh nyata terhadap hasil dan tidak berpengaruh nyata terhadap berat 100 biji (Tabel 4). Dari data pada Tabel 4 terlihat bahwa perbedaan sistem persiapan lahan tidak memberikan pengaruh yang nyata terhadap berat 100 biji dan hasil.Hal ini menunjukan bahwa pada pola pertanaman jagung secara berurutan sepanjang musim tidak memerlukan pengolahan yang intensif karena struktur tanahnya sudah gembur karena pada setiap musim tanam selalu diolah dan untuk persiapan lahan selanjutnya harus dengan pertimbangan yang lebih efektif dan efisien. Sedangkan pemberian bahan organik sebanyak 2 t/ha dapat meningkatkan hasi jagung dari 6,07 menjadi $6,85 \mathrm{t} / \mathrm{ha}$ atau terjadi peningkatan hasil sebesar $780 \mathrm{~kg} / \mathrm{ha}$. Lahan yang selalu diusahakann secara intensif sepanjang musim akan mengalami penurunan kadar bahan oranik dan penurunan kecepatan penyediaan unsur hara bari agi tanaman terutama N, P dan $\mathrm{K}$ (Badan Litbang Pertanian, 2001),hal ini akan berdampak terhadap penurunan hasil pada pertanaman jagung selanjutnya. Sehingga untuk mempertahankan dan meningkatkan hasil jagung setiap musim tanam pemberian bahan organik dalam bentuk pupuk kandang ataupun kompos sangat diperlukan. Pemberian bahan organik sangat penting artinya dalam pengelolaan kesuburan tanah. Pemberian bahan organik dalam bentuk pupuk kandang selain dapat menyumbang sejumlah unsure hara yangtidak terdapat pada pupuk an organik juga penting artinya terhadap perbaikan sifat-sifat fisis, kimia dan biolagi tanah (Soepardi, 2001). Secara umum terlihat bahwa produktivitas jagung yang dicapai pada kegiatan ini masih tergolong rendah atau belum mencapai maksimal yaitu masih di bawah 7,0 t/ha, pada pada kondisi yang optimal jagung hibrida dapat memberikan hasil di atas 8,0 t/ha. 
Tabel. 4. Pengaruh persiapan lahan lahan dan pemberian bahan organik terhadap berat 100 biji Dan hasil jagung, Koto Baru Simalanggang, Kabupaten 50 Kota MK. 2007.

\begin{tabular}{|c|c|c|}
\hline \hline Perlakuan & $\begin{array}{c}\text { Berat 100 biji } \\
(\mathrm{g})\end{array}$ & $\begin{array}{c}\text { Hasil } \\
(\mathrm{t} / \mathrm{ha})\end{array}$ \\
\hline Sistem Persiapan Lahan & & \\
TOT & $29,2 \mathrm{~A}$ & $6,16 \mathrm{~A}$ \\
KLD & $29,7 \mathrm{~A}$ & $6,63 \mathrm{~A}$ \\
ODB & $29,4 \mathrm{~A}$ & $6,59 \mathrm{~A}$ \\
& $29,3 \mathrm{a}$ & $6,07 \mathrm{~b}$ \\
Takaran B. Organik (t/ha) & $29,5 \mathrm{a}$ & $6,85 \mathrm{a}$ \\
2 & & \\
\hline
\end{tabular}

Angka-angka selajur yang diikuti oleh huruf sama tidak berbeda nyata pada UBD $(\mathrm{p}=0,05)$

Hal ini antara lain disebabkan jumlah curah hujan selama pertumbuhan tanaman masih rendah (Tabel 5) Untuk mencapai hasil yang maksimal jagung mebutuhkan curah hujan sebanyak $200 \mathrm{~mm} /$ bulan, dengan distribusi yang merata. Jumlah curah hujan yang tinggi dibutuhkan oleh tanaman jagung adalah pada saat pertumbuhan vegetatif , pembungaan dan pengisian biji.. Meskipun tanaman masih dapat memberikan hasil pada kondisi curah hujan yang terbatas tetapi pembentukan biji pada tongkol tidak sempurna, ukuran biji yang terbentuk lebih kecil dan tidak mencapai berat yang maksimal

Tabel. 5. Data curah hujan selama kegiatan (April - Agustus 2007), Koto Baru Simalnggang

\begin{tabular}{|l|r|r|}
\hline \multicolumn{1}{|c|}{ Bulan } & Curah Hujan $(\mathrm{mm})$ & Hari Hujan (hr) \\
\hline 1. Januari & 198 & 17 \\
2. Februari & 117 & 6 \\
3. Maret & 44 & 20 \\
4. April & 212 & 11 \\
5. Mei & 127 & 15 \\
6. uni & 75 & 9 \\
7. Juli & 53 & 9 \\
8. Agustus & 192 & 13 \\
9. September & 260 & 13 \\
10.Oktober & 415 & 19 \\
11.November & 204 & 12 \\
12. Desember & 304 & 15 \\
\hline
\end{tabular}

MK 2007.

Sumber : Stasiun Klimatologi Tanjung Pati Kabupaten 60 Kota (2007) 


\section{KESIMPULAN}

1. Lahan tempat penelitian selalu ditanami jagung sepanjang musim, masih masih termasuk lahan yang subur, untuk pertanaman jagung selanjutnya perlu pengelolaan yang lebih intensif melalui pemupukan, pemberian bahan organik dan penerapan sistem pengolahan tanah yang tepat, berwawaasn konservasi dan lebih efisien.

2. Perbedaan sistem pengolahan tanah tidak memberikan pengaruh yang nyata terhadap tinggi tnaman, panjang tongkol, lingkaran tongkol, jumlah baris biji/tongkol, jumlah biji/baris, berat 100 biji dan hasil, dengan sistem KLD sedikit mamberikan hasil yang lebih tinggi dari pada sistem TOTdan ODB, sistem KLD dapat memberikan hasil sebesar 6,63 t/ha, sedangkan TOT dan ODB memberikan hasil 6,16 dan 6,59 t/ha.

3. Untuk melelengkapi bahan organik insitu pemberian bahan organik dalam bentuk pupuk kandang masih diperlukan. Dengan pemberian bahan organik dalam bentuk pupuk kandang 2 t/ha dapat meningkatkan hasil sebesar $0,78 \mathrm{t} / \mathrm{ha}$ atau $780 \mathrm{~kg} / \mathrm{ha}$. Tanpa pemberian bahan organik hasil yang dicapai hanya sebesar 6,07 t/ha dengan pemberian bahan organik $2 \mathrm{t} / \mathrm{ha}$ meningkat menjadi $6,85 \mathrm{t} / \mathrm{ha}$

4. Secara umum hasil yang dicapai pada masing-masing perlakuan masih rendah karena jumlah curah hujan selama pertumbuhan tanam rendah.dan belum mendukung pertumbuhan tanaman untuk berproduksi secara maksimal.

\section{DAFTAR PUSTAKA}

Abduracman, A., A. Dariah., dan A. Mulyani. 2008 . Strategi dan teknologi pengelolaan lahan kering mendukung pengadaan pangan nasional. Jurnal Penelitian dan Pengembangan Pertanian Vol. 27 (2) : 43 - 54. Badan Litbang Pertanian'

Badan Litbang Peranian. 2001. Pengelolaan tanaman terpadu : Pendekatan inovatif sistem Produksi padi Warta Penelitian dan Pengembangan Pertanian .Vol. 23 (2) : $3-5$.

Badan Litbang Petanian. 2008. PTT jagung meningkatkan produksi dan pendapatan. Warta Penelitian dan Pengembangan Pertanian Vol. 30 (2) : $1-4$.

BPTP Sumbar. 2002. Sistem usahatani terpadu pangan dan ternak, spesifik lokasi (Crops livestock system). Laporan Akhir Kegiatan 2002.

Foth, H. D. 1988. Dasar-dasar ilmu tanah, E. Dwipurbaynti et al (penerjemah). Universitas Diponegoro, Gajah Mada Press $782 \mathrm{hlm}$.

Hardjowigeno, S.. 1987. Ilmu tanah. Penerbit Medyatama Sarana Perkasa Jakarta $220 \mathrm{hlm}$.

Parker, W. B. 1983. How No tillage farming can work for you. Crops and Soil Magazine. Krol D. M, W.R Luelen and $\mathrm{K}$ Schlesinger (eds) The Amer. Soc. Of Agron. P. 11- 13.

Soepardi , G. M. Ismunadji dan S. Partohardjono. $1985 . \quad$ Menuju pemupukan berimbang guna meningkatkan jumlah dan mutu hasil pertanian. Dirjentan $63 \mathrm{hlm}$. 
Soepardi, H.G. 2001. Strategi usahatani agribisnis berbasis sumberdaya lahan. hlm. 35-52.. Pros 